\title{
Mycotoxin's Infections and Prevention Methods: State of the Art
}

\author{
Ishimwe Viviane ${ }^{1 *}$, Emmanuel Masabo ${ }^{1,2}$, Habiyaremye Joseph ${ }^{1}$, Mitsindo Rene ${ }^{1}$, Elias Bizuru ${ }^{1}$ \\ ${ }^{1}$ African Center of Excellence in Internet of Things, University of Rwanda, Kigali, Rwanda \\ ${ }^{2}$ African Center of Excellence in Data Science, University of Rwanda, Kigali, Rwanda \\ Email: *vivianeishimwe36@gmail.com
}

How to cite this paper: Viviane, I., Masabo, E., Joseph, H., Rene, M. and Bizuru, E. (2021) Mycotoxin's Infections and Prevention Methods: State of the Art. Agricultural Sciences, 12, 1269-1285.

https://doi.org/10.4236/as.2021.1211081

Received: September 3, 2021

Accepted: November 12, 2021

Published: November 15, 2021

Copyright (c) 2021 by author(s) and Scientific Research Publishing Inc. This work is licensed under the Creative Commons Attribution International License (CC BY 4.0).

http://creativecommons.org/licenses/by/4.0/ (c) (P) Open Access

\begin{abstract}
Fungi that attack field crops and contaminate agricultural commodities produce mycotoxins when conditions are favorable. These are specialized metabolites made of poisonous chemical compounds created by bacteria, fungi, or plants that aren't involved in the organism's usual growth, development, or reproduction. They have an adversarial hold on humans, wildlife, and the agricultural sector, resulting in mysterious ailments and economic disruptions. Mycotoxins-tainted food and fodder can be found all over the world, posing a global concern. Consumption of contaminated food and fodder is a typical cause of epidemic outbreaks. Other mycotoxins have been associated with esophageal cancer and neural tube defects (NTDs); the immunotoxin deoxynivalenol (DON) causes diarrhea when combined with trichothecenes, and ochratoxin A (OTA) has been linked to kidney failure. The direct market costs associated with missed trade or lower revenues owing to tainted food or feed could be viewed as the economic repercussions of mycotoxins on human society. This review describes frequent groups of mycotoxins in detail, their impact on global health, their impact on the socio-economy; the methods of detection and prevention of these mycotoxins.
\end{abstract}

\section{Keywords}

Mycotoxins, Global Health Impact, Socio-Economy Impact, Mycotoxin's Detection, Prevention Methods

\section{Introduction}

\subsection{Meaning of the Topic}

Mycotoxin refers to the toxic chemical products that are produced by fungi (molds) grown on numerous foodstuffs such as cereals, direct fruits, nuts, and 
spices, often under warm and humid conditions. This indicates that it is a harmful secondary metabolite produced by fungal species and they are harmful to humans, animals, and plants [1]. Dry matter, quality, and nutritional losses are the results of molds and mycotoxins contamination on cereal commodities and this represents a major hazard to the food chain; as this one can be found in food, it is capable of causing disease and death in both humans and livestock. Mycotoxins are carcinogenic, genotoxic, teratogenic, nephrotoxic, and hepatotoxic chemicals that can infect a wide variety of foods [2].

\subsection{Background}

Toxic fungus and mycotoxins initially infiltrated human food sources around 10,000 years ago, when humans learned to harvest crops and store them from one season to the next. Fungi pathogenic on grain crops or saprophytic on harvested grain has found a wide new biological niche in cereal storage, with many of them producing mycotoxins. Mycotoxins are climate-dependent chemicals, but other factors, such as micronutrient bioavailability and insect damage, can influence their occurrence, making it a complicated and multifactor phenomenon [3]. The majority of disorders are caused by eating mycotoxin-contaminated grain or items made from such grain, however, there are additional ways to be exposed [4]. Because the symptoms of mycotoxicoses are similar to those caused by other drugs, so diagnosing them can be difficult. As a result, proper testing for mycotoxins, which includes sampling, sample preparation, and analysis, is required for the diagnosis of a mycotoxicosis.

\subsection{Current Status of the Study}

Many recent studies have focused on the existence of Mycotoxins in foodstuffs, but the research question is: "Can mycotoxins attacks be avoided in cereals"? While there has been much research on mycotoxins infections in cereals, few researchers have taken into consideration how to avoid these infections to avail cereals that are free from mycotoxins.

To estimate the possibility of contamination prevention and their inactivation or reduction for the case where the incident is inevitable, it is necessary to understand the potential of the harmful effect of mycotoxins, to know the terms of mycotoxins occurrence and frequency, toxicity, and biotransformation in different animal species and humans. Currently, over 400 mycotoxins have been found and classified; however, scientists are concentrating their efforts on those that are carcinogenic or poisonous [5].

\section{Main Body}

\subsection{Mycotoxins Natural Occurrence}

Cereals are highly represented in human and animal diet, industrial food, and feed, all these may become contaminated by molds that produce mycotoxins. 
Lately, about 400 different mycotoxins were described as produced mostly by molds from genera of Aspergillus, Penicillium, Fusarium, and Trichotecium, among which a smaller number is associated with the occurrence of acute or chronic intoxications. It is very difficult to uniquely classify them and create order, because of their different chemical structure, biochemical pathway, origin, and biological effects [6]. The most important are aflatoxin B1, ochratoxin A, zearalenone, deoxynivalenol, fumonisin B1, and T-2 toxin [7] (Figure 1).

The majority of mycotoxins are produced by three fungal genera: Aspergillus, Penicillium, and Fusarium. These metabolites primarily affect the seed quality, germination, viability, seedling vigor, growth of root and coleoptile, since the fungi responsible for the production of these mycotoxins are often endophytes that infect and colonize living plant tissues, accumulation of mycotoxins in the plant tissues may at times be associated with the development of plant disease symptoms [1].

While fusarium toxins are known to be created during cereal harvesting under high moisture conditions, pre-harvest aflatoxin contamination of crops is linked to high temperatures, insect-mediated damage, and extended dryness. In warm, humid, tropical, and subtropical growing environments, chronic contamination occurs. The amount of moisture in the grain depends mostly on the amount of water available at harvest, but it also depends on the frequency and extent of drying and aerating the grain before and during storage, as well as the respiration of insects and microbes hosted by the grain. The present state of knowledge about the natural occurrence, metabolism, and potential toxicity of the most major trichothecenes and zearalenone in cereals/cereal products has been reviewed [8].

Zearalenone is also a mycotoxin that can be produced by several field fungi including the Fusarium variety. Fusarium infects cereals pre-harvest in the field during blooming, but growth and toxin production may also occur post-harvest under poor storage conditions [9].

Below, are the chemical structures of the main mycotoxins.

Table 1 outlines the most prominent mycotoxins, as well as the food and animal feed restrictions set by the United States (US) and the European Union (EU).

Recommendations have been made regarding the presence of T-2 and HT-2 toxin in grains and grain products [10].

\section{Parameters That Influence the Occurrence of Mycotoxins}

Aflatoxins are produced in response to pre-harvest and post-harvest conditions. The pre-harvest factors are [12]:

- Weather conditions related to droughts.

- Infection is increased by heat stress during flowering and fruit growth.

- Excessive water.

- Nutrient deficiency. 


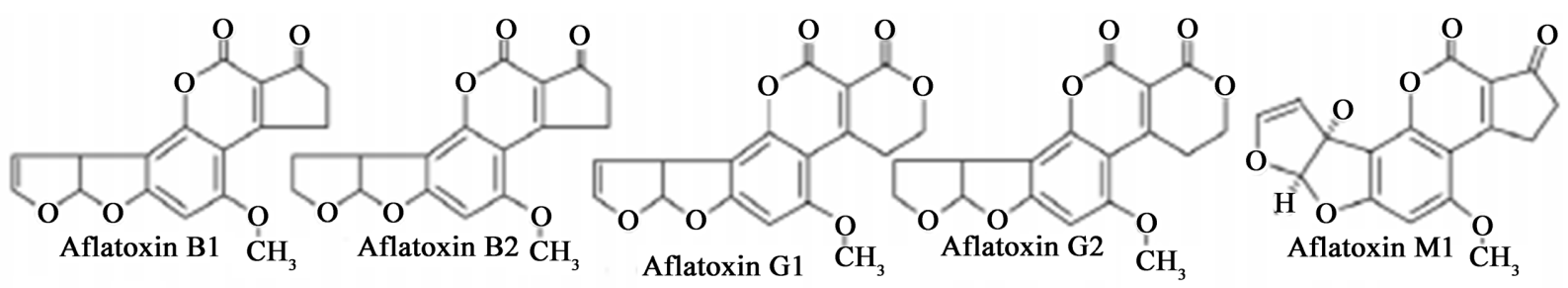<smiles>C[C@H]1Cc2c(Cl)cc(C(=O)N[C@@H](Cc3ccccc3)C(=O)O)c(O)c2C(=O)O1</smiles>

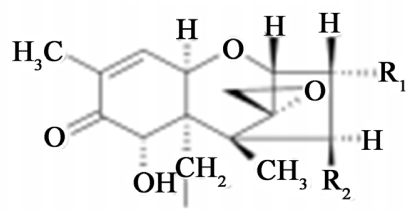<smiles>[R2]C(CCCCCCC([R1])C[R]([H])([H])[H])CC(OC(=O)CC(CC(=O)O)C(=O)O)C(OC(=O)CC(CC(=O)O)C(=O)O)C(C)CCCC</smiles><smiles>CCCCCC(=O)CCCC=Cc1cc(O)cc(O)c1C(=O)O</smiles>

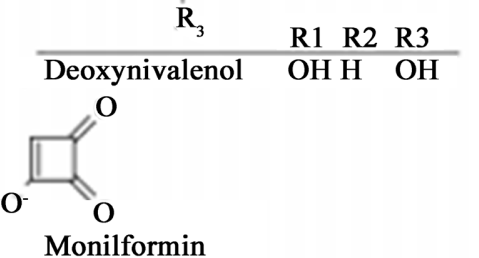<smiles>[R3]C(C(=O)OC(C(=O)N(C)C([R1])C(=O)OC(C(=O)N(C)C([R2])C(=O)OC(C(C)C)C(C)C)C(C)C)C(C)C)N(C)C</smiles>

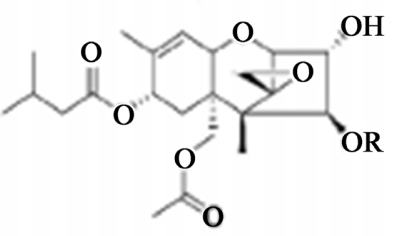<smiles>[R]c1cc(O)c2c(=O)oc3cc(O)cc([Y]#[W])c3c2c1</smiles>

$\mathrm{R}=\mathrm{AC} \quad \mathrm{T}-2$ toxin $\mathrm{R}=\mathrm{H}$ HT-2 toxin

Enniatin A R1=R2=R3= $\mathrm{CH}\left(\mathrm{CH}_{3}\right) \mathrm{CH}_{2} \mathrm{CH}_{3}$ Enniatin A1 R1 $=\mathrm{R} 2=\mathrm{CH}\left(\mathrm{CH}_{3}\right) \mathrm{CH}_{2} \mathrm{CH}_{3}, \mathrm{R} 3=\mathrm{CH}\left(\mathrm{CH}_{3}\right)_{2}$ Enniatin B R1=R2=R3 $=\mathrm{CH}\left(\mathrm{CH}_{3}\right)_{2}$ EnniatinB1 R1 $=\mathrm{CH}\left(\mathrm{CH}_{3}\right) \mathrm{CH}_{2} \mathrm{CH}_{3}, \mathrm{R} 2=\mathrm{R} 3=\mathrm{CH}\left(\mathrm{CH}_{3}\right)_{2}$ Enniatin B2 R1=R2=R3= $\mathrm{CH}\left(\mathrm{CH}_{3}\right)_{2}$

Figure 1. Chemical structures of the main mycotoxins [2].

- Insect damage.

- Harvest damage.

- Other stressors in plants that promote fungal infection and aflatoxin formation, includes:

$>$ Inadequate dietary intake.

$>$ Plant illnesses.

$>$ Weed competition.

$>$ Overgrowth of plants.

$>$ Insect nourishment for growing fruits.

Higher aflatoxins concentrations in post-harvest products are caused by improper product storage, which includes storage with insufficient moisture content and at an inappropriate temperature.

Additionally, some parameters have to be considered during drying and storage of cereals after harvesting, these include: [12].

- Temperature is one of the products of respiration of the crop that produces heat, As a result, lowering the temperature of the crop can help to reduce the rate of respiration, extending the crop's storage life by reducing the chance of germination. 
Table 1. List of the most common mycotoxins and their maximum levels in diet and feed [11].

\begin{tabular}{|c|c|c|c|c|c|c|}
\hline Mycotoxin & $\begin{array}{l}\text { IARC } \\
\text { Number* }\end{array}$ & Acronym & Fungal species & Food commodities & $\begin{array}{l}\text { US FDA } \\
(\mu \mathrm{g} / \mathrm{Kg})\end{array}$ & $\mathrm{EU}(\mu \mathrm{g} / \mathrm{Kg})$ \\
\hline $\begin{array}{l}\text { Aflatoxins B1, B2, } \\
\text { G1, G2 }\end{array}$ & $1^{\star}$ & $\begin{array}{l}\text { AFB1 AFB2 } \\
\text { AFG1 AFG2 }\end{array}$ & $\begin{array}{l}\text { Aspergillus flavus } \\
\text { Aspergillus parasiticus }\end{array}$ & $\begin{array}{l}\text { Maize, wheat, rice, } \\
\text { peanut, sorghum, } \\
\text { pistachio, almond, } \\
\text { ground nuts, tree nuts, } \\
\text { figs, cottonseed, spices }\end{array}$ & 20 for total & $\begin{array}{l}2-12 \text { for B1 } 4 \\
-15 \text { for total }\end{array}$ \\
\hline Aflatoxin M1 & $2 \mathrm{~B}^{\star}$ & AFM1 & Metabolite of Aflatoxin B1 & $\begin{array}{l}\text { Milk, mik products, } \\
\text { meat }\end{array}$ & 0.5 & $\begin{array}{l}0.05 \text { in milk } \\
0.025 \text { in infant } \\
\text { formulae and } \\
\text { infant milk }\end{array}$ \\
\hline Ochratoxin A & $2 \mathrm{~B}^{\star}$ & OTA & $\begin{array}{l}\text { Aspergillus Ochraceus } \\
\text { Aspergillus carbonarius } \\
\text { Penicillium verrucosum } \\
\text { Penicillium Nordicum }\end{array}$ & $\begin{array}{l}\text { Cereals, dried vine, } \\
\text { fruits, wine, grapes, } \\
\text { coffee, cocoa, cheese }\end{array}$ & Not set & $2-10$ for $\mathrm{EU}$ \\
\hline $\begin{array}{l}\text { Fumonisins B1, B2, } \\
\text { B3 }\end{array}$ & $2 B^{*}$ & $\begin{array}{l}\text { FB1 FB2 } \\
\text { FB3 }\end{array}$ & $\begin{array}{l}\text { Fusarium verticillioides } \\
\text { Fusarium proliferatum }\end{array}$ & $\begin{array}{l}\text { Maize, maize products, } \\
\text { sorghum, asparagus }\end{array}$ & $2000-4000$ & $2000-4000$ \\
\hline Zearalenone & $3^{*}$ & ZEN & $\begin{array}{l}\text { Fusarium Graminearum } \\
\text { (F.roserum) Fusariu } \\
\text { culmorum Fusarium } \\
\text { Equiseti Fusarium cerealis } \\
\text { Fusarium verticillioides } \\
\text { Fusarium incarnatum }\end{array}$ & $\begin{array}{l}\text { Cereals, cereal products, } \\
\text { maize, wheat, barley }\end{array}$ & Not set & $20-100$ \\
\hline $\begin{array}{l}\text { Trichothecenes } \\
\text { (Type B: } \\
\text { deoxynivalenol) }\end{array}$ & $3^{*}$ & $\mathrm{DON}$ & $\begin{array}{l}\text { Fusarium Graminearum } \\
\text { Fusariu culmorum } \\
\text { Fusarium cerealis }\end{array}$ & Ceareals, cereal products & 1000 & $200-500$ \\
\hline Patulin & $3^{*}$ & PAT & $\begin{array}{l}\text { Penicillium Expansum } \\
\text { Bysoclamus nivea } \\
\text { Aspergillius clavatus } \\
\text { penicilium patulum } \\
\text { penicillius crutosum }\end{array}$ & $\begin{array}{l}\text { Apples, apple juice and } \\
\text { concentrate pears, } \\
\text { peachs, grapes, apricots, } \\
\text { olives low acid fruit juice }\end{array}$ & 50 & $10-50$ for $\mathrm{EU}$ \\
\hline $\begin{array}{l}\text { Trichothecenes } \\
\text { (Type A: T-2 } \\
\text { toxins) }\end{array}$ & $3^{*}$ & $\mathrm{~T}-2$ & $\begin{array}{l}\text { fusarium langsethiae } \\
\text { Fusarium sporotrichioides }\end{array}$ & $\begin{array}{l}\text { Maize, wheat, barley, } \\
\text { oat, rye }\end{array}$ & 15 & $25-1000$ \\
\hline $\begin{array}{l}\text { Trichothecenes } \\
\text { (Type A: HT-2) }\end{array}$ & $3^{*}$ & HT-2 & $\begin{array}{l}\text { fusarium langsethiae } \\
\text { Fusarium sporotrichioides }\end{array}$ & $\begin{array}{l}\text { Maize, wheat, barley, } \\
\text { oat, rye }\end{array}$ & 15 & $25-1000$ \\
\hline Enniatins & & ENNs & $\begin{array}{l}\text { Fusarium tricinctum } \\
\text { Fusarium avenaccum }\end{array}$ & Corn & Not set & Not set \\
\hline Ergot Alkaloids & & Eas & $\begin{array}{l}\text { Claviseps purpurea } \\
\text { claviseps fusiformis } \\
\text { claviseps africana } \\
\text { Neotyphodium spp }\end{array}$ & $\begin{array}{l}\text { Rye, rye-containing } \\
\text { commodities, wheat, } \\
\text { tritical, barley, millet and } \\
\text { oat }\end{array}$ & Not set & Not set \\
\hline Alternariol & & $\mathrm{AOH}$ & Alternaria alternata & $\begin{array}{l}\text { Grain and grain-based } \\
\text { products, vegetables, }\end{array}$ & Not set & Not set \\
\hline
\end{tabular}


- The other parameter is moisture since it fosters fungal and insect problems, respiration, and germination, high moisture content causes storage issues.

- The other parameter is Oxygen in the storing container because foods store best when oxygen is removed, eliminating oxygen minimizes food oxidation and deterioration.

Table 2 shows the sources and conditions for mycotoxins formation.

\subsection{Toxic Effects of Mycotoxins on Health}

Poor postharvest handling can result in a rapid loss of qualitative features, as well as a considerable decrease in seed germinability and nutritional content. Microbial activity in grains can cause discoloration, contribute to heating and dry matter losses by using carbohydrates as an energy source, degrade lipids and proteins or alter their digestibility, produce volatile metabolites that emit odors, reduce germination, baking, and malting quality, and have an impact on use as animal feed or seed [14]. Some fungus spores can cause respiratory illness in workers who come into contact with them [1].

Mycotoxins are silent killers, and their effects might go undetected for a long time, especially if they are exposed regularly. When consumed or inhaled, these fungal toxins cause a variety of metabolic dysfunctions in humans and livestock, including immunological imbalance, malignancies, allergies, abortions, and, in rare circumstances, the death of the affected hosts [15].

The role of aflatoxins in the formation of liver cell cancer, developmental

Table 2. Sources and conditions for mycotoxins formation [13].

\begin{tabular}{|c|c|c|c|c|c|}
\hline Mycotoxins & Mold source & Grains affected & $\begin{array}{l}\text { Optimal } \\
\text { temperature }\end{array}$ & Optimal Humidity & Favorabe conditions \\
\hline $\begin{array}{l}\text { Aflatoxins (B1, } \\
\text { B2, G1, G2) }\end{array}$ & $\begin{array}{l}\text { Aspergillus flavus } \\
\text { Aspergillus parasiticus }\end{array}$ & $\begin{array}{l}\text { Corn, sorghum, } \\
\text { cotton seed, } \\
\text { peanuts }\end{array}$ & $75-95^{\circ} \mathrm{F}$ & $\begin{array}{l}80 \%-85 \% \text { relative } \\
\text { humidity } 17 \% \\
\text { moisture content }\end{array}$ & $\begin{array}{l}\text { Grain damage, } \\
\text { constant high } \\
\text { temperature and } \\
\text { humidity }\end{array}$ \\
\hline $\begin{array}{l}\text { Vomitoxin } \\
\text { (deoxynivalenol, } \\
\text { DON) }\end{array}$ & Fusarium Graminearum & $\begin{array}{l}\text { Corn, wheat, barley, } \\
\text { sorghum, rye, } \\
\text { others }\end{array}$ & $70-82^{\circ} \mathrm{F}$ & $\begin{array}{l}88 \% \text { relative humidity } \\
22 \% \text { moisture content }\end{array}$ & $\begin{array}{l}\text { alternating warm and } \\
\text { cool temperatures } \\
\text { during growing season, } \\
\text { high humidity }\end{array}$ \\
\hline Zearalenone & Fusarium Graminearum & $\begin{array}{l}\text { Corn, wheat, barley, } \\
\text { sorghum }\end{array}$ & $45-75^{\circ} \mathrm{F}$ & $24 \%$ moisture content & $\begin{array}{l}\text { alternating warm and } \\
\text { cool temperatures } \\
\text { during growing season }\end{array}$ \\
\hline $\begin{array}{l}\text { Fumonisins B1, } \\
\text { B2, B3 }\end{array}$ & Fusarium verticillioides & Corn & Likely $<77^{\circ} \mathrm{F}$ & $\begin{array}{l}\text { likely }>20 \% \text { moisture } \\
\text { content }\end{array}$ & $\begin{array}{l}\text { Drought during } \\
\text { growing season, } \\
\text { followed by cool, wet } \\
\text { conditions }\end{array}$ \\
\hline Ochratoxin A & $\begin{array}{l}\text { Aspergillus Ochraceus } \\
\text { Penicillium verrucosum } \\
\text { Penicillium viricatum }\end{array}$ & $\begin{array}{l}\text { Corn, wheat, barley, } \\
\text { rye }\end{array}$ & $54-77^{\circ} \mathrm{F}$ & $\begin{array}{l}85 \% \text { relative humidity } \\
19 \%-22 \% \text { moisture } \\
\text { content }\end{array}$ & Low temperatures \\
\hline
\end{tabular}


impairment, acute toxicosis, fumonisins, esophageal cancer, and neural tube abnormalities has been a source of concern for humans (NTDS). Deoxynivalenol (DON) and other immunotoxin trichothecenes cause gastroenteritis, whereas ochratoxin A (OTA) has been associated with kidney disease [16]. Fumonisin intake from contaminated corn and corn-based products has been associated with neural tube anomalies [17].

In animals, mycotoxins can cause everything from instant death to chronic sickness and reproductive problems; aflatoxins can induce liver damage or cancer, as well as decreased milk and egg production and immune suppression [12] [18].

Several writers have addressed the toxicity and biological impacts of mycotoxins in foods [19] [20] [21] (Table 3).

Table 4 shows the commodities where mycotoxins have been discovered, as well as the impacts on animals and humans [12].

\subsection{Mycotoxin's Detection and Control}

According to a review paper on Strategies to prevent and reduce mycotoxins for compound feed manufacture, mycotoxin reduction approaches can be divided

Table 3. Mycotoxins' toxicity and biological consequences in food [21].

\begin{tabular}{|c|c|c|c|c|}
\hline Mycotoxin & Major foods & Species & Health effects & $\mathrm{LD}(\mathrm{mg} / \mathrm{Kg})$ \\
\hline Aflatoxins & $\begin{array}{l}\text { Maize, groundnuts, figs, tree } \\
\text { nuts, (aflatoxins M1 } \\
\text { secreted by cow after } \\
\text { metabolism of aflatoxin B1), } \\
\text { milk, milk products) }\end{array}$ & $\begin{array}{l}\text { Aspergillus flavus Aspergillus } \\
\text { parasiticus }\end{array}$ & Hepatotoxic, carcinogenic & $\begin{array}{l}0.5(\mathrm{dog}) 9.0 \\
\text { (mouse) }\end{array}$ \\
\hline Cyclopiazonic acid & $\begin{array}{l}\text { Cheese, maize, groundnuts, } \\
\text { rodo millet }\end{array}$ & $\begin{array}{l}\text { Aspergillus flavus Penicillium } \\
\text { aurantiogriseum }\end{array}$ & Convulsions & 36 (rat) \\
\hline Deoxynivalenol & Cereals & Fusarium Graminearum & Vomiting, Food refusal & 70 (mouse) \\
\hline $\mathrm{T}-2$ toxins & Cereals & Fusarium sporotrichioides & Alimentary toxic aleuki & 4 (rat) \\
\hline Ergotamine & Rye & Claviseps purpurea & Neurotoxin & \\
\hline Fumonisins & Maize & Fusarium moniliforme & Eusophesial cancer & \\
\hline Ochratoxin & Maize, cereals, coffee beans & $\begin{array}{l}\text { Aspergillus Ochraceus } \\
\text { Penicillium verrucosum }\end{array}$ & Nephotoxic & $20-30$ (rat) \\
\hline Palutin & Apple juice, damaged apple & Penicillium expansum & $\begin{array}{l}\text { Edema, hemorrhage, } \\
\text { possibly cancer }\end{array}$ & 35 (mouse) \\
\hline Penitrem & Walnuts & Penicillium aurantiogriseum & Tremors & $1-0.5$ (mouse) \\
\hline Sterigmatocystin & $\begin{array}{l}\text { Cereals, coffee, beans, } \\
\text { cheese }\end{array}$ & Aspergillus versicolor & Hepatotoxic cancer & 166 (rat) \\
\hline Tenuazonic acid & Tomato paste & Alternaria tenuis & Convulsions, hemorrhage & $\begin{array}{l}81 \text { (female mouse) } \\
186 \text { (female mouse) }\end{array}$ \\
\hline Zearalenone & Maize, barley, Wheat & Fusarium Graminearum & Oestrogenic & Not acutely toxic \\
\hline
\end{tabular}


Table 4. Commodities containing mycotoxins and their impact on animals and humans [12].

\begin{tabular}{|c|c|c|c|}
\hline Mycotoxins & $\begin{array}{l}\text { Commodities found } \\
\text { contaminated }\end{array}$ & Affected species & Pathological effects \\
\hline $\begin{array}{l}\text { Aflatoxins (B1, } \\
\text { B2, G1, G2, M1, } \\
\text { M2) }\end{array}$ & $\begin{array}{l}\text { Peanuts, corn, wheat, maize, } \\
\text { cottonseed, nuts, various food, } \\
\text { milk, eggs, cheese, figs }\end{array}$ & $\begin{array}{l}\text { Birds(Duckling, turkey, chicken, } \\
\text { Mammals (cattle, sheep, lab } \\
\text { animals) fish) }\end{array}$ & $\begin{array}{l}\text { hepatoxicity, bile duct hyperplasia, } \\
\text { hemorrhage, intestiinal track, kidneys, } \\
\text { carcinogenesis (liver tumors) }\end{array}$ \\
\hline Ochratoxin & $\begin{array}{l}\text { Cereal grains (wheat, barley, } \\
\text { corn) dry beans, cheese, } \\
\text { coffee, dried fruits, grapes, } \\
\text { wine }\end{array}$ & Chicken, duckling, rat, human & $\begin{array}{l}\text { Nephrotoxicity (tubular nephrosis of kidney), } \\
\text { porcine nephrogalthy, mild liver damage, } \\
\text { teratogenesis, carcinogenesis (Kidney } \\
\text { tumors), urinary tract tumors }\end{array}$ \\
\hline Fumonisins & Corn, polenta & Horse, rat, mouse, humans & $\begin{array}{l}\text { Pumonary edema, Leukoencephalomalacia, } \\
\text { nephrotoxicity, hepatoxicity }\end{array}$ \\
\hline Zearalenone & $\begin{array}{l}\text { corn, moldy hay, elletted } \\
\text { commercial feed }\end{array}$ & $\begin{array}{l}\text { Dairy cttle, chicken, turkey, } \\
\text { lamb, rat, mouse }\end{array}$ & $\begin{array}{l}\text { Estrogenic effects (Edema of vulva prolapse of } \\
\text { vagine),enlargement of uterus, atrophy of } \\
\text { testicles, trophy of ovaries, enlargement of } \\
\text { mammary glands, abortion }\end{array}$ \\
\hline
\end{tabular}

into four categories: Physical methods, thermal methods, chemical methods, and mycotoxin-controlling feed additives are all examples of mycotoxin-controlling feed additives. The first three methodologies primarily focus on reducing mycotoxins in feed ingredients during processing, whereas the last one focuses on compensating for the negative effects of mycotoxin-contaminated diets in animal bodies, and that mycotoxin prevention management and the processing stage of cleaning and sorting are still the most effective strategies to control mycotoxin hazards in a current era [22].

To control mycotoxins in foods and feeds, a variety of techniques are used. These tactics could be divided into preventive and curative strategies on a broad scale.

\subsubsection{Preventive Strategies of Mycotoxins}

Pre-harvest and post-harvest methods are two types of prophylactic techniques for preventing mycotoxigenic fungal development and/or the production of their toxin. There are three degrees of fungal and associated mycotoxins protection in agricultural commodities: primary, secondary, and tertiary prevention [12].

1) Primary prevention entails a variety of activities aimed at keeping the environment unfavorable for fungal growth, these includes:

- Establishing a pre-harvest schedule that is appropriate.

- Fungal types of growing plants are being developed.

- Managing fungi-infected planting crops in the field.

- Reducing the moisture content of plant seeds upon harvest and during storage.

- Whenever feasible, keep commodities at a low temperature.

- Fungicides and preservatives are used to prevent fungal development.

- Use approved insecticides to control insect infestations in stored bulk grains. 
Grain dryer control systems can be used to increase drier throughput while maintaining optimal energy efficiency and minimizing grain quality degradation. The three most common methods for drying cereal grains are in-storage layer drying, batch drying, and continuous flow drying [23].

2) Secondary prevention deals with early prevention if some fungi infect commodities at an early stage. This includes:

- Re-drying items to stop the growth of infected fungus.

- Seeds that have been infected must be removed.

- Detoxification or inactivation of mycotoxins that have been contaminated.

- Keeping kept goods safe from conditions that foster fungus growth.

3) Tertiary prevention is applied, when products are heavily infested with dangerous fungus. This includes:

- Complete eradication of tainted goods.

- Mycotoxins are detoxified or destroyed to a minimum amount.

The first step for being able to reduce mycotoxins in cereals is to be able to detect them early, The development of electronic nose technology has generated interest in using characteristic volatiles and fragrances as a rapid, early indicator of grain quality decline to detect quality changes in cereal grains [24].

Mycotoxins can be kept out of the food chain if only high-quality items are stored in silos and suitable farming practices are followed. Decontamination of mycotoxin in the later phases of food production is challenging; it raises production costs and the outcomes aren't always good. A review of mycotoxin contamination prevention in food and feed provided agronomical approaches, food and feed storage guidelines, practical feed decontamination procedures, and the use of feed additives where mycotoxin contamination prevention has failed [25].

\subsubsection{Curative Strategies on Mycotoxins Detection and Control}

Deactivation of existing mycotoxins in feed or food is one of the therapeutic approaches [15]. To decontaminate/detoxify mycotoxins from various agricultural products, natural methods (physical treatment) such as thermal insulation, radiation treatment, and low-temperature plasma, chemical methods such as oxidation, reduction, hydrolysis, alcoholysis, and absorption, and biological methods with the use of biological agents can all be used [2].

\section{1) Physical treatment}

Mycotoxins are naturally removed through a variety of methods. Sorting, processing, storage, radiation, cold plasma, and mycotoxins binders are a few of them.

Sorting is the initial step in natural disinfection, which is accomplished by cleaning and sorting processes. Because aflatoxin infection is typically diverse, separating damaged nuclei can significantly limit infection. A reduction of 27 percent to 93 percent is projected after sorting the diseased grain. This process is considered preferable because there is no risk of manufacturing degraded items [26]. 
Processing: Although mycotoxins are thermally stable molecules, they have been demonstrated to be diminished by several traditional food preparation processes (baking, frying) at temperatures surpassing $1000^{\circ} \mathrm{C}$. The processing temperature and moisture content of the granules have an impact on the decrease of mycotoxins by $50 \%$ to $80 \%$ during the extrusion process. Furthermore, temperatures between 150 and 2000 degrees Celsius significantly reduce aflatoxin (AFB1), with an average drop of 79 percent, and are much more effective at high humidity levels [27].

Storage: Controlling mycotoxins is complicated by environmental factors. Temperature and humidity are two essential variables that boost both fungal growth and the manufacture of mycotoxins because they affect the total growth of fungus. Storage under controlled environments, such as packing, temperature control, ventilation, and proper air humidity, helps to prevent fungal growth and the accumulation of mycotoxins. Crop losses have ranged from $20 \%$ to $50 \%$ in underdeveloped countries due to insufficient storage techniques [28].

Radiation is usually classified as ionizing and non-ionizing. It contributes to the reduction or elimination, Mycotoxins are a natural detoxifying agent for pathogenic microbes in grains, although they are only partially eliminated in diets. This technology can be used in an industrial setting because it distributes energy and modifies the molecular structure of food items through a series of reactions [29].

Cold plasma (CP) Plasma is a word for the fourth state of matter, which is mostly made up of photons, ions, and free radicals such as reactive oxygen and nitrogen species, all of which have specific physical and chemical properties. Using low-pressure cold plasma, researchers were able to detoxify up to $50 \%$ of aflatoxins on the surface of nuts. However, due to the lack of information on the possible creation of hazardous chemicals, this approach should be used with caution [30].

Mycotoxin binders attach to mycotoxins and prevent them from entering the bloodstream through the gut, preventing mycotoxins from being absorbed. Absorbent compounds include activated carbon, aluminosilicates, complicated non-digestible polysaccharides, and cholesterol. Binding mycotoxin is a physical method of stopping bacteria from degrading aflatoxins [31]. Activated carbon was used to eliminate patulin from naturally contaminated cider and aflatoxin from naturally infected milk, according to studies [32]. Mycotoxins levels were lowered using this method, but more research is needed to ensure food safety.

To eliminate, destroy, or suppress the toxicity of mycotoxins, many physical procedures have been revised. Physical removal of contaminated areas of foodstuffs, heat treatment, and irradiation to transform toxins into comparatively benign chemicals, or the inclusion of adjuvants to reduce or otherwise hide the adverse effects of toxins are examples of these procedures. These treatments include food drying and roasting, irradiation, bio-absorption of aflatoxins in animal feed, and other ozone-based methods [15]. 
In 2004-2005, the Lithuanian University of Agriculture, Laboratory of Heat and Biotechnological Engineering investigated the efficacy of physical means (ozone) for reducing mycological pollution of grain surfaces, as well as the use of ozone for reducing mycological infection in cereal grain to clean grain from microbiological contamination. Based on moisture content $\mathrm{w}$ (for grain $\mathrm{w}=15.2$ percent) to 3 times (for grain $\mathrm{w}=22.0$ percent), an ozone-air mixture used for active ventilation grain drying (with an ozone concentration of $700 \mathrm{ppb}$ ) can reduce drying time by roughly $20 \%$, and mycological pollution by about 2.2 percent) $[33]$.

\section{2) Chemical treatment}

This can be achieved using bases (ammonia, hydrated oxide), chitosan, ozone treatment.

Bases (ammonia, hydrated oxide) are used to treat seeds with ammonia to reduce the number of mycotoxins (AFs, FBs, OTs) to undetectable levels while blocking mycotoxigenic fungal growth. Treatment with bases, on the other hand, is prohibited in the European Union for food meant for human consumption. Mycotoxin detoxification was aided greatly by the use of a glycerol and calcium hydroxide combination. Although sodium hydroxide and potassium hydroxide are commonly used to break down AFB1 in tainted oil, these chemicals have the potential to cause secondary contamination and have poor nutritional effects on the commodities [29].

Chitosan is a linear polymer that inhibits fungi, bacteria, and viruses. It is the second most abundant carbohydrate in nature after cellulose. Chitosan's biocompatibility and antibacterial characteristics make it a promising candidate for food preservation [34]. The combined effects of chitosan on maize and wheat grains for controlling fungal growth and mycotoxin production of FBs and DON by Fusarium species ( $F$. proliferatum, $F$. graminearum, and $F$. verticilliodes) were reported, showing a decrease in DON and FB production in irradiated maize and wheat grains after the application of low-molecular-weight chitosan with deacetylation above $70 \%$. Furthermore, wheat grains containing 1 percent chitosan and 1 percent lemon essential oils from the marine brown algae Ascophyllum nodosum had decreased DON levels [35].

Ozone treatment deals with Ozone therapy by applying ozone $\left(\mathrm{O}_{3}\right)$ to aid in the breakdown of certain mycotoxins. Ozonation is a straightforward procedure that leaves no hazardous leftovers after use [36]. Ozone is used to sterilize cereals, vegetables, and fruits, as well as to detoxify mycotoxins [37]. Because aflatoxins, particularly AFB1 and AFG1, have a C8 - C9 double bond in their structures, Agriopoulo et al. discovered that ozone gas was particularly effective in destroying them [38]. Aflatoxin AFG1 was discovered to be the most sensitive. Ozone therapy resulted in a significant reduction in DON under optimum conditions (55 $\mathrm{g} \mathrm{O}_{3}-1$ for 6 hours) (29 percent - 32 percent) [39].

\section{3) Biological control}

This is done by using the bacteria treatment method, Yeast application me- 
thod, food fermentation, applying non-toxic fungi, and enzymatic detoxification.

The bacteria treatment method is useful since certain bacteria can bind mycotoxins in food or liquids, they are used in the bacteria treatment strategy. Flavobacterium aurantiacum B-184 was the only bacteria out of over 1000 evaluated for probable aflatoxins degradation that was capable of irreversibly eliminating aflatoxins from solutions [40]. The bacterium Enterococcus faecium detoxifies AFB1 by adhering to the bacterium's cell wall components. With the help of microorganisms, peptidoglycans and polysaccharides found in bacterial cell walls were found to be responsible for the binding of mycotoxins [41]. Furthermore, bacterial detoxification of the mycotoxin DON has evolved as a result of research and improvements. Aerobic oxidation and partitioning of DON into C3 carbon, which is carried by various Devosia species, can reduce DON pollution. Lactic acid bacteria (Lactobacillus (L.) casei and Lactobacillus reuter) may successfully bind to aflatoxins in aqueous solutions [22]. In additional in vitro experiments, Lactobacillus amylovorus and Lactobacillus rhamnosus demonstrated a binding efficacy of up to $60 \%$ AFB1, showing their potential to bind specific dietary contaminants. A reduction of 98 percent $\mathrm{FB} 1$ and 84 percent $\mathrm{T}-2$ was also reported during fermentation of whole-grain sorghum with Lactobacillus fermentum [42].

The yeast application approach is a potential technique for mycotoxin infection therapy that involves the use of biological control agents (BCA) [43]. The use of yeast is particularly interesting since yeast produces antimicrobial compounds that are beneficial to people and animals; yet, yeasts may quickly grow on any substrate in bioreactors [44]. Moreover, yeasts do not produce allergens or other secondary compounds, unlike many filamentous fungi or bacterial antagonists [45]. Saccharomyces cerevisiae is a probiotic yeast that digests DON and reduces the synthesis of lactate dehydrogenase (LDH) in DON-stimulated cells [46].

Food fermentation is utilized to improve food while also making it more appealing to consumers. Fermentation is a low-cost mycotoxin disinfection technology that can be used to improve food ingredients while also lowering or eliminating mycotoxins. Fermentation is a more cost-effective and practical way to reduce mycotoxins than the more costly and inconvenient options. The nature of metabolites and the toxicity of products formed after fermentation should be thoroughly documented for safe food production.

Applying Fungi done by the application of fungus to maize, cotton, pistachio, and peanuts using non-toxic strains of A. flavus and A. parasiticus resulted in considerable reductions in aflatoxins contamination. In terms of fungus and detoxification, it has been discovered that fungi that create Mycotoxins can also degrade them [47]. When fungi are starving for energy, they can degrade, convert, and use degradation products as a source of energy. Fungi including Aspergillus, Rhizopus, Trichoderma, Clonostachys, and Penicillium spp. successfully detoxify mycotoxins. In both west and east Africa, competition is used to 
suppress Aflatoxins in maize with non-toxigenic microbial strains. Non-toxic A. parasiticus inoculants, in large quantities, enter the soil around the crops, competing with toxigenic strains [48].

Enzymatic Detoxification: here the chemical and biological processing aspects of Enzymatic Detoxification of Mycotoxins are combined. It has excellent performance and specialization, and it may be utilized in low-toxicity situations without harming organisms. In non-stoichiometric mycotoxin ratios, enzymes also behave as catalysts [49]. Some species of Aspergillus can produce an enzyme that can detoxify fumonisins, including those produced by Fusarium. The anti-infection activity of enzymes like 1,3-glucanases and chitinase varies depending on the microorganism's characteristics. Fruit rotting fungus growth is slowed and reduced when -1,3-glucanases and chitinases are used [50]. A.Niger complex Penicillium simplicissiumun is suppressed. The growth of Penicillium nalgiovense and A. flavus was enhanced by spraying 50 percent 1,3-glucanase and 50 percent and 40 percent chitinase on salami surface samples. As a result, 1,3-glucanase and chitinase could be employed as a safe alternative in the fermented sausage industry to control fungal deterioration. Using microbial manganese peroxide, oxidase enzymes, catalase, and laccase enzymes, enzymatic detoxification of AFB1 was also achieved [48]. Enzymes, on the other hand, have an untapped profile when it comes to detoxifying food toxins due to their favorable toxicity and specificity [51]. In the European Union, no enzyme for eliminating mycotoxin contamination from foods has been approved.

\subsection{Effects of Mycotoxins on the Economy}

The direct market costs of lost commerce or poorer revenues as a result of polluted food or feed can be considered the economic consequences of mycotoxins on human society [16]. This occurs in systems that monitor the presence of mycotoxins in food and feed supplies [52]. Food with mycotoxin levels beyond a specified maximum allowed level is either rejected outright or sold at a lower price for a different purpose in local markets or even on a global scale. As a result, food producers face enormous financial losses [53].

Due to its location near the equator, which makes it particularly favorable to the multiplication of mycotoxigenic fungus species, Africa is the most impacted of all continents. Poverty and climate change are two other variables that are complicating the continent's mycotoxins problem. In Africa, the economic impact of mycotoxins can be felt in overall human and animal health, sustainable development, food security and safety, damage to Africa's agricultural export brand, decreased self-sustainability, and increased reliance on foreign aid, not to mention the high cost of research, mitigation, and regulation of mycotoxins' prevalence [54].

\section{Conclusion}

According to this research study, mycotoxins are common in grains and feed. To 
prevent animal exposure to various mycotoxins, which might have detrimental repercussions for animal health and production output, special attention should be made to certain raw materials. As a result, human health and the occurrence of residues in animal-derived products may be compromised indirectly. In humans and animals, several mycotoxins have been reported to have teratogenic and genotoxic effects, as well as synergistic effects. Furthermore, relevant approaches for the further development and application of sophisticated specific methodologies for the detection and reduction of mycotoxin contamination may be found in the literature. It is recommended that nationwide monitoring be carried out on a large number of grains and feed samples in a systematic manner.

\section{Conflicts of Interest}

The authors declare no conflicts of interest regarding the publication of this paper.

\section{References}

[1] Ismaiel, A.A. and Papenbrock, J. (2015) Mycotoxins: Producing Fungi and Mechanisms of Phytotoxicity. Agriculture, 5, 493-537.

https://doi.org/10.3390/agriculture5030492

[2] Agriopoulou, S., Stamatelopoulou, E. and Varzakas, T. (2020) Advances in Occurrence, Importance, and Mycotoxin Control Strategies: Prevention and Detoxification in Foods. Foods, 9, Article No. 137. https://doi.org/10.3390/foods9020137

[3] Smith, M.C., Madec, S., Coton, E. and Hymery, N. (2016) Natural Co-Occurrence of Mycotoxins in Foods and Feeds and Their in Vitro Combined Toxicological Effects. Toxins, 8, Article No. 94. https://doi.org/10.3390/toxins8040094

[4] Richard, J.L. (2007) Some Major Mycotoxins and Their Mycotoxicoses-An Overview. International Journal of Food Microbiology, 119, 3-10. https://doi.org/10.1016/j.ijfoodmicro.2007.07.019

[5] Selamat, J. and Iqbal, S.Z. (2016) Food Safety: Basic Concepts, Recent Issues, and Future Challenges. Springer, Berlin, $160 \mathrm{p}$.

[6] Pleadin, J. (2015) Mycotoxins in Grains and Feed-Contamination and Toxic Effect in Animals. Biotechnology in Animal Husbandry, 31, 441-456. https://doi.org/10.2298/BAH1504441P

[7] Krogh, P. (1978) Mycotoxicoses of Animals. Mycopathologia, 65, 43-45. https://doi.org/10.1007/BF00447172

[8] Bryła, M., Waśkiewicz, A., Ksieniewicz-Woźniak, E., Szymczyk, K. and Edrzejczak, R.J. (2018) Modified Fusarium Mycotoxins in Cereals and Their Products-Metabolism, Occurrence, and Toxicity: An Updated Review. Molecules, 23, Article No. 963. https://doi.org/10.3390/molecules23040963

[9] European Food Safety Authority (2004) Opinion of the Scientific Panel on Contaminants in the Food Chain [CONTAM] Related to Zearalenone as Undesirable Substance in Animal Feed. The EFSA Journal, 2, 1-35. https://doi.org/10.2903/j.efsa.2004.89

[10] The European Commission (2013) Recommendations on the Presence of T-2 and HT-2 Toxin in Cereals and Cereal Products. Official Journal of the European Un- 
ion, $56,12-15$.

[11] Torelli, E., Firrao, G., Bianchi, G., Saccardo, F. and Locci, R. (2012) European Commission Regulation No. 1126/2007 Amending Regulation (EC) No 1881/2006 Setting Maximum Levels for Certain Contaminants in Foodstuffs as Regards Fusarium Toxins in Maize and Maize Products. Journal of the Science of Food and Agriculture, 92, 479-487.

[12] Abdel-Wahh, M.A. and Kholif, A.M. (2010) Mycotoxins in Animal Feeds and Prevention Strategies: A Review. Asian Journal of Animal Sciences, 4, 113-131. https://doi.org/10.3923/ajas.2010.113.131

[13] Telephone, E. (2020) Safety Data Sheet: Aflatoxin B1: 1. Identification of the Substance/Mixture and of the Company. 6 p.

[14] Magan, N., Sanchis, V. and Aldred, D. (2003) The Role of Spoilage Fungi in Seed Deterioration. Marcel Dekker, Inc., New York.

[15] Enyiukwu, D.N., Awurum, A.N. and Nwaneri, J.A. (2014) Mycotoxins in Stored Agricultural Products: Implications to Food Safety and Health and Prospects of Plant-Derived Pesticides as Novel Approach to Their Management. Greener Journal of Microbiology and Antimicrobials, 2, 32-48.

[16] Yvv, A.K. (2016) Mycotoxin Strategies: Impact on Global Health and Wealth. Pharmaceutica Analytica Acta, 7, 1-11.

[17] Missmer, S.A., et al. (2006) Exposure to Fumonisins and the Occurrence of Neutral Tube Defects along the Texas-Mexico Border. Environmental Health Perspectives, 114, 237-241. https://doi.org/10.1289/ehp.8221

[18] CAST (1989) Mycotoxins: Economic and Health Risks. Report No. 116. Council for Agricultural Science and Technology, Ames, IA.

[19] WHO (2011) Children's Health and the Environment. $42 \mathrm{p}$.

[20] Takata, Y., Hidaka, H., Ishida, K. and Kobayashi, T. (2013) Giant Cell Reparative Granuloma of the Temporal Bone Successfully Resected with Preservation of Hearing. The Journal of Laryngology \& Otology, 127, 716-720.

https://doi.org/10.1017/S002221511300114X

[21] Skovgaard, N. (2002) Evaluation of Certain Mycotoxins in Food. World Health Organization Technical Report Series, 906, 62 p.

[22] Peng, W.X., Marchal, J.L.M. and Van der Poel, A.F.B. (2018) Strategies to Prevent and Reduce Mycotoxins for Compound Feed Manufacturing. Animal Feed Science and Technology, 237, 129-153. https://doi.org/10.1016/j.anifeedsci.2018.01.017

[23] Farouq, O., Noor, S. and Marhaban, M.H. (2008) Some Control Strategies in Agricultural Grain Driers: A Review. Journal of Food Agriculture and Environment, 6, 74-85.

[24] Magan, N. and Evans, P. (2000) Volatiles as an Indicator of Fungal Activity and Differentiation between Species, and the Potential Use of Electronic Nose Technology for Early Detection of Grain Spoilage. Journal of Stored Products Research, 36, 319-340. https://doi.org/10.1016/S0022-474X(99)00057-0

[25] Peraica, M., Domijan, A.M., Jurjević, Ž. and Cvjetković, B. (2002) Prevention of Exposure to Mycotoxins from Food and Feed. Archives of Industrial Hygiene and Toxicology, 53, 229-237.

[26] Shi, H., Stroshine, R.L. and Ileleji, K. (2014) Aflatoxin Reduction in Corn by Cleaning and Sorting. ASABE 2014 Annual International Meeting, 1, 311-321.

[27] Stryken, J. (2003) Cleaning Solutions. World Cem., 2, 5-8. 
[28] Iqbal, S.Z., Abdull Razis, A.F., Usman, S., et al. (2021) Variation of Deoxynivalenol Levels in Corn and Its Products Available in Retail Markets of Punjab, Pakistan and Estimation of Risk Assessment. Toxins, 13, Article No. 296.

[29] Sipos, P., et al. (2021) Physical and Chemical Methods for Reduction in Aflatoxin Content of Feed and Food. Toxins, 13, Article No. 204.

https://doi.org/10.3390/toxins13030204

[30] Ten Bosch, L., Pfohl, K., Avramidis, G., Wieneke, S., Viöl, W. and Karlovsky, P. (2017) Plasma-Based Degradation of Mycotoxins Produced by Fusarium, Aspergillus and Alternaria Species. Toxins, 9, Article No. 97. https://doi.org/10.3390/toxins9030097

[31] Whitlow, L. (2006) Evaluation of Mycotoxin Binders. Proceedings of the 4th Mid-Atlantic Nutrition Conference, Baltimore, 29-30 March 2006, 132-143. http://manc.umd.edu/documents/2006 complete proceedings.pdf \#page $=138$

[32] Ullah, H.A., et al. (2016) Dietary Mycotoxins Binders: A Strategy to Reduce Aflatoxin $\mathrm{m} 1$ Residues and Improve Milk Quality of Lactating Beetal Goats. Journal für Verbraucherschutz und Lebensmittelsicherheit, 11, 305-309. https://doi.org/10.1007/s00003-016-1046-0

[33] De Mil, T., et al. (2015) Characterization of 27 Mycotoxin Binders and the Relation with in Vitro Zearalenone Adsorption at a Single Concentration. Toxins (Base), 7, 21-33.

[34] Zachetti, V.G.L., Cendoya, E., Nichea, M.J., Chulze, S.N. and Ramirez, M.L. (2019) Preliminary Study on the Use of Chitosan as an Eco-Friendly Alternative to Control Fusarium Growth and Mycotoxin Production on Maize and Wheat. Pathogens, 8, Article No. 29. https://doi.org/10.3390/pathogens8010029

[35] Mart, K., et al. (time) The Effect of Edible Chitosan Coatings Incorporated with Thymus capitatus Essential Oil on the Shelf-Life of Strawberry (Fragaria $x$ ananassa) during Cold Storage. Biomolecules, 8, Article No. 155.

[36] Soares, C., et al. (2020) Use of IoT to Real-Time Monitoring of Storage Silo and Ozone Gas Fungal Decontamination Strategy. International Journal of Computers and Applications, 175, 1-7.

[37] Zhuang, K., et al. (2020) Effect of Different Ozone Treatments on the Degradation of Deoxynivalenol and Flour Quality in Fusarium-Contaminated Wheat. CyTA-Journal of Food, 18, 776-784. https://doi.org/10.1080/19476337.2020.1849406

[38] Wang, L., et al. (2016) Effect of Ozone Treatment on Deoxynivalenol and Wheat Quality. PLoS ONE, 11, e0147613. https://doi.org/10.1371/journal.pone.0147613

[39] Li, M., Guan, E. and Bian, K. (2019) Structure Elucidation and Toxicity Analysis of the Degradation Products of Deoxynivalenol by Gaseous Ozone. Toxins, 11, Article No. 474. https://doi.org/10.3390/toxins11080474

[40] Wang, L., et al. (2019) Aflatoxin B1 Degradation and Detoxification by Escherichia Coli CG1061 Isolated from Chicken Cecum. Frontiers in Pharmacology, 9, Article ID: 1548. https://doi.org/10.3389/fphar.2018.01548

[41] Nešić, K., Habschied, K. and Mastanjević, K. (2021) Possibilities for the Biological Control of Mycotoxins in Food and Feed. Toxins, 13, Article No. 198. https://doi.org/10.3390/toxins13030198

[42] Majumdar, R., Kandel, S.L., Cary, J.W. and Rajasekaran, K. (2021) Changes in Bacterial Endophyte Community Following Aspergillus flavus Infection in Resistant and Susceptible Maize Kernels. International Journal of Molecular Sciences, 22, Article ID: 3747 . https://doi.org/10.3390/ijms22073747 
[43] Tilocca, B., Balmas, V., Hassan, Z.U., Jaoua, S. and Migheli, Q. (2019) A Proteomic Investigation of Aspergillus carbonarius Exposed to Yeast Volatilome or to Its Major Component 2-Phenylethanol Reveals Major Shifts in Fungal Metabolism. International Journal of Food Microbiology, 306, Article ID: 108265. https://doi.org/10.1016/j.ijfoodmicro.2019.108265

[44] Mendieta, C.R., Gomez Verduzco, G., Del Río, J.C.G., Cuevas, A.C., Arce, J.M. and Ávila, E.G. (2018) Effect of the Addition of Saccharomyces cerevisiae Yeast Cell Walls to Diets with Mycotoxins on the Performance and Immune Responses of Broilers. The Journal of Poultry Science, 55, 38-46.

[45] Zhang, Z., Li, M., Wu, C. and Peng, B. (2019) Physical Adsorption of Patulin by Saccharomyces cerevisiae during Fermentation. Journal of Food Science and Technology, 56, 2326-2331. https://doi.org/10.1007/s13197-019-03681-1

[46] Jakopović, Ž., et al. (2018) Properties and Fermentation Activity of Industrial Yeasts Saccharomyces cerevisiae, S. uvarum, Candida Utilis and Kluyveromyces marxianus Exposed to AFB 1 , OTA and ZEA. Food Technology and Biotechnology, 56, 208-217. https://doi.org/10.17113/ftb.56.02.18.5582

[47] Alberts, J.F., Lilly, M., Rheeder, J.P., Burger, H.M., Shephard, G.S. and Gelderblom, W.C.A. (2017) Technological and Community-Based Methods to Reduce Mycotoxin Exposure. Food Control, 73, 101-109. https://doi.org/10.1016/j.foodcont.2016.05.029

[48] Sarrocco, S., Mauro, A. and Battilani, P. (2019) Use of Competitive Filamentous Fungi as an Alternative Approach for Mycotoxin Risk Reduction in Staple Cereals: State of Art and Future Perspectives. Toxins, 11, Article No. 701. https://doi.org/10.3390/toxins11120701

[49] Lyagin, I. and Efremenko, E. (2019) Enzymes for Detoxification of Various Mycotoxins: Origins and Mechanisms of Catalytic Action. Molecules, 24, Article ID: 2362 .

[50] Lyagin, I. and Efremenko, E. (2019) Enzymes for Detoxification of Various Mycotoxins. 1-39.

[51] Shanakhat, H., Sorrentino, A., Raiola, A., Romano, A., Masi, P. and Cavella, S. (2018) Current Methods for Mycotoxins Analysis and Innovative Strategies for Their Reduction in Cereals: An Overview. Journal of the Science of Food and Agriculture, 98, 4003-4013. https://doi.org/10.1002/jsfa.8933

[52] Pitt, J.I., et al. (2012) Economics of Mycotoxins: Evaluating Costs to Society and Cost-Effectiveness of Interventions. IARC Scientific Publications, Lyon, 119-129. http://www.ncbi.nlm.nih.gov/pubmed/23477200

[53] Bhat, R. and Vasanthi, S. (1999) Occurrence of Aflatoxin and Its Economic Impact on Human Nutrition and Animal Feed Natural Occurrence. Agriculture et développement, No. 23, 3 p.

[54] Gbashi, S., et al. (2019) The Socio-Economic Impact of Mycotoxin Contamination in Africa. Mycotoxins-Impact and Management Strategies. https://doi.org/10.5772/intechopen.79328 